\title{
GEOCACHING JAKO INNOWACYJNA FORMA ODKRYWANIA WALORÓW PRZYRODNICZYCH I KULTUROWYCH W POLSCE STUDIUM PRZYPADKU POWIATU POZNAŃSKIEGO1
}

\begin{abstract}
Abstrakt: Autorka artykułu, będąca mieszkanką Poznania, a jednocześnie zaawansowanym graczem geocachingu, podjęła próbę prezentacji powiatu poznańskiego jako obszaru, który posiada potencjał do rozwoju tej gry. Świadczą o tym tworzone w ostatnich latach trasy, jak również działania regionalnej organizacji - GEOpyry oraz nastawienie mieszkańców. Do przygotowania opracowania wykorzystano analizę literatury, źródeł internetowych związanych z geocachingiem oraz wyniki badań własnych zrealizowanych na potrzeby pracy magisterskiej za pośrednictwem kwestionariusza ankiety na próbie 355 mieszkańców powiatu poznańskiego, w okresie od października 2016 r. do marca 2017 r.
\end{abstract}

Słowa kluczowe: geocaching, powiat poznański, gra terenowa, krajoznawstwo.

\section{GEOCACHING AS AN INNOVATIVE WAY OF DISCOVERING NATURAL AND CULTURAL ASSETS IN POLAND POZNAŃ POWIAT CASE STUDY}

Abstract: Currently, many Polish towns, through various organizational structures, use geocaching to promote local tourist values. This paper presents case studies of large cities, rural areas as well as valuable natural areas. The author of this article, as a resident of Poznan and an advanced geocaching player, has attempted to present the Poznan province as an area that has the potential to develop such field games. This is evidenced both by the routes created in recent years as well as by the regional organization - GEOpyra and the attitude of the inhabitants. Literature analysis, Internet sources related to geocaching and the results of our own research (conducted through a questionnaire survey on a sample of 355 inhabitants of the Poznan province from October 2016 to March 2017) were used to prepare the study.

Keywords: geocaching, Poznan province, field game, sightseeing.

\section{ISTOTA I FUNKCJE GEOCACHINGU}

Ze względu na fakt, iż geocaching jest stosunkowo nową formą aktywnego wypoczynku trudno wskazać przykłady literatury naukowej, które ukazywałyby analizowane zjawisko w sposób całkowity i wyczerpujący. Autorka posiłkowała się wiedzą innych - najbardziej znanych osób ze świata geocachingu, które chętnie dzieliły się swoimi doświadczeniami zarówno na portalach społecznościowych, jak i w specjalistycznych pismach oraz innych publikacjach. Ponadto autorka (jako pasjonatka geocachingu) korzystała z własnej wiedzy nabywanej podczas wielu spotkań i wypraw.

Wyraz "geocaching" pochodzi od angielskiego pojęcia „cache” (kesz), które oznacza kryjówkę, skrytkę, schowek, nawiązując tym samym do ukrywana skarbów (Wielki słownik angielsko-polski, polsko-angielski 2012). Geo, czyli Ziemia, wyróżnia zarówno globalny charakter tej zabawy, jak i miejsce ukrycia przedmiotu. Słowem "geocache" określa się więc ukryty pojemnik prze- znaczony do wytropienia, a keszerem (geocacher, geokeszer) człowieka zajmującego się geocachingiem, czyli angażującego się i w ukrywanie, i odnajdywanie skrzynek (SMOLEŃSKA 2009).

Oprócz przytoczonych powyżej określeń, termin "geokeszer" opiera się na wielu charakterystycznych pojęciach, tworząc swoisty, zakodowany język graczy. Jak powszechnie wiadomo, odszukanie ukrytych skarbów możliwe jest dzięki zastosowaniu nowoczesnej technologii. Zabawa wykorzystuje bowiem sygnał GPS odbierany przez specjalne urządzenia lub aplikacje umieszczone $\mathrm{w}$ telefonach komórkowych nowej generacji czy tabletach. Według zasad gry tylko dzięki znajomości długości i szerokości geograficznej możliwe jest chowanie i odszukiwanie keszy.

W kontekście powyższego stwierdzenia istotne jest wydarzenie z 2000 r. Właśnie wtedy, 1 maja, prezydent Bill Clinton ogłosił, że Stany Zjednoczone udostępnią cywilnym użytkownikom sygnał GPS bez 
zniekształceń. Ułatwiło to poprawę dokładności wyszukiwanej lokalizacji do kilku metrów (wcześniej dokładność nawigacji GPS do celów cywilnych wynosiła ok. 100 m) (SHERMAN 2004). Już 3 maja 2000 r. Dave Ulmer ukrył pierwszą skrytkę ze "skarbami” niedaleko miejscowości Estacade w stanie Oregon, a następnie umieścił współrzędne kryjówki na forum internetowym. Wkrótce wielu ludzi zaczęło poszukiwania skrzynki za pomocą odbiorników GPS i dzieliło się swoimi wrażeniami na internetowym forum. Osoby, którym nie wystarczały same poszukiwania, zaczęły ukrywać własne skrzynki. Fakt ten jest uznawany za narodziny geocachingu oraz jego istotnego narzędzia - strony internetowej geocaching.com (DOBEK, KOZIEE 2015). Pomysł, by wykorzystać nawigację satelitarną do zlokalizowania skrzynek, okazał się przysłowiowym strzałem w dziesiątkę i odpowiedzią na potrzeby współczesnych pokoleń. Tylko na początku 2000 r. strona geocaching.com zawierała lokalizacje 75 keszy, a ich liczba systematycznie rosła. Obecnie skrytki rozsiane są po całym świecie; 19.04.2017 r. było ich około 3 mln (https:/ / www.geocaching.com/blog/...). Należy nadmienić, iż pierwsza polska skrzynka pojawiła się już w 2002 r.

Współcześnie geocaching spełnia wiele funkcji, począwszy od typowo hedonistycznych i rekreacyjnych, przez integracyjną, a skończywszy na jakże istotnej roli poznawczej $\mathrm{w}$ odniesieniu do walorów turystycznych danego regionu. Warto podkreślić, że w Stanach Zjednoczonych gra została włączona do wszystkich poziomów klas szkół podstawowych i znalazła zastosowanie - jako sposób „nauka przez zabawę" - w wielu przedmiotach. Na przykład w nauce geografii ułatwia odczytywanie map i umiejętność stosowania nawigacji, a na lekcjach historii zachęca do zwiedzania lokalnych zabytków (MATHERSON i in. 2008).

W Polsce również zaczęto doceniać siłę oddziaływania geocachingu jako jednego $\mathrm{z}$ ważniejszych narzędzi współczesnego krajoznawstwa. Potencjał ten wykorzystują obecnie coraz chętniej lokalne władze, a także różne organizacje $\mathrm{w}$ celu promowania walorów miejscowości czy regionu.

\section{PRZYKŁADY INICJATYW GEOCACHINGOWYCH NA TERENIE POLSKI}

Rosnącą popularność geocachingu w Polsce zaczęli dostrzegać przedstawiciele różnych struktur organizacyjnych zarówno dużych miast, jak i małych miejscowości. Dzięki zaangażowaniu jednostek samorządowych umożliwiono odkrywanie fascynujących miejsc, o których milczą przewodniki. Także współudział mieszkańców sprzyja promocji regionu, jego kultury, historii oraz odkrywaniu uroków danego miejsca. Władze gmin, wspólnie z lokalnymi organizacjami turystycznymi, poprzez organizowanie zabaw związanych z aktywnym wykorzystaniem wolnego czasu, podejmują działania związane $\mathrm{z}$ wyznaczaniem geocachingowych "tras". Niebagatelne znaczenie ma w tej kwestii działalność Stowarzyszenia Geocaching Polska, działającego formalnie od 2012 r. Członkiem Stowarzyszenia może zostać zarówno osoba fizyczna, jak i prawna. Zwykle są to doświadczeni geokeszerzy, aktywnie zainteresowani realizacją celów organizacji lub wspierający jej działania. Władzami stowarzyszenia są: Walne Zebranie, Zarząd i Komisja Rewizyjna - wybierane w głosowaniu jawnym i pełniące swe funkcje honorowo (\$18 Statutu) przez 4-letnią kadencję.

Do podstawowych zadań Stowarzyszenia należą (§ 6 Statutu): ochrona środowiska i działalność kulturalna związana ze zwiedzaniem zabytków i poszerzaniem wiedzy na temat historii oraz poznawaniem przyrody żywej i nieożywionej, a co za tym idzie pozyskiwanie informacji na temat jej powstawania, funkcjonowania i odgrywanej roli w życiu człowieka. Wśród ważnych działań wymienić należy także upowszechnianie wiedzy o geocachingu, poszerzanie grona miłośników i sympatyków gry, promocję i poprawę walorów estetycznych oraz krajobrazowych Polski, inicjowanie i podejmowanie działań na rzecz świadomości historycznej oraz znajomości dziedzictwa narodowego, a także propagowanie turystycznych i kulturowych walorów kraju, działalność wspomagającą wychowanie dzieci i młodzieży oraz wzmacnianie więzi międzyludzkich i międzypokoleniowych (https:/ / www.geocaching.org.pl/stowarzy szenie/statut). Stowarzyszenie aktywnie wspiera lokalne społeczności geokeszerów poprzez pomoc w szkoleniach, organizację spotkań edukacyjnych, czy też wsparcie w kontaktach $\mathrm{z}$ urzędami administracji rządowej i samorządowej, których zgoda jest wymagana na określone działania uczestników zabawy. Dotyczy to zwłaszcza możliwości rozmieszczenia skrzynek na atrakcyjnych kulturowo i przyrodniczo terenach prawnie chronionych. Zasady gry muszą być bowiem zgodne $\mathrm{z}$ porządkiem prawnym obowiązującym na obszarze Rzeczypospolitej Polskiej (https://www.geo caching.org.pl/stowarzyszenie/kim-jestesmy).

Należy podkreślić, że statuty Polskiego Towarzystwa Turystyczno-Krajoznawczego i Stowarzyszenia Geocaching Polska w wielu swych założeniach sa zbieżne. Obie organizacje są otwarte na nowych członków, popularyzują wiedzę o atrakcyjnych turystycznie regionach kraju, promują turystykę aktywną, rozwijają pasję odkrywania lokalnego piękna regionów i chęć wspólnego działania. Dowodem na współpracę PTTK, Stowarzyszenia Geocaching Polska i portalu geocaching.pl jest ustanowienie Uchwałą Zarządu 
Głównego PTTK nr 311/XVII/ 2012 z 25.02.2012 r. odznaki PTTK Geocaching Polska, która służy upowszechnianiu geocachingu oraz popularyzacji walorów krajoznawczych i turystycznych Polski, a także zobowiązuje do poszanowania zasobów dziedzictwa naturalnego i kulturowego (postanowienie ogólne regulaminu PTTK Geocaching Polska (http://www. pttk.pl).

Ustanowioną na podstawie art. 9 ust. 2 pkt. 7 i art 28 ust. 2 pkt. 17 Statutu PTTK oraz $\S 4$ pkt. 17 Regulaminu ZG PTTK, w porozumieniu z portalem Geocaching Polska, Zarząd Główny PTTK odznakę dzieli na cztery stopnie: popularną, brązową, srebrną i złotą. Chcąc zdobyć pierwszą - popularną, wystarczy odnaleźć 100 skrytek na terenie całego kraju. Upowszechnianie wiedzy na temat geocachingu przez te dwie znane organizacje sprzyja wykorzystywaniu założeń wspomnianej gry terenowej w skali regionu czy miejscowości. Obecnie widać wyraźnie rosnące zainteresowanie pomysłem w różnych częściach kraju, co obrazują przedstawione poniżej przykłady.

\section{GEOCACHING W MIASTACH POWYŻE] 100 TYS. MIESZKAŃCÓW}

W sierpniu 2015 r. Gdańska Organizacja Turystyczna zaprosiła miłośników poszukiwania „skarbów” za pośrednictwem odbiornika GPS do udziału w grze "Szukajcie, a zwiedzicie". Rozwinięcie w mieście darmowej sieci internetowej i wykorzystanie hot-spotów miejskiego Internetu GD@ŃSKwifi pozwoliło uczestnikom zabawy na umiejscowienie skrytek. Do gry wytypowanych zostało dziesięć lokalizacji w obrębie śródmieścia wartych pokazania zarówno mieszkańcom, jak i turystom. Geokeszerzy poznali fakty, legendy i ciekawostki związane m.in. z Pomnikiem Poległych Stoczniowców, Domem Harcerza, ulicą Mariacką oraz Targami: Węglowym, Długim i Drzewnym (http:// ibedeker.pl). Oprócz gwarantowanej zabawy na znalazców skrzynek czekały nagrody w postaci talonów upoważniających do otrzymania biletów wstępu do muzeów, Gdańskiego Teatru, Europejskiego Centrum Solidarności i Latarni Morskiej w Gdańsku - Nowym Porcie (http:/ / www.gdansk.pl).

Chcąc poczuć atmosferę krakowskiego geocachingu należy udać się na Kopiec Kościuszki, gdzie para keszerów Karl-Olav and Ania założyła 27.10.2004 r. pierwszą skrytkę, która dzięki opiece lokalnych wolontariuszy służy zabawie po dziś dzień (do 14.03. 2017 r. odnalazły ją 563 osoby). Po jej odkryciu warto zwrócić uwagę na otaczający krajobraz prezentujący zabudowania grodu Kraka. Większość skrytek w mieście znajduje się właśnie $\mathrm{w}$ miejscach, które ukazują urokliwe, tajemnicze lub nieznane zakątki Krakowa, a jedną z najpiękniej umieszczonych - przy murach Zamku Królewskiego, skąd rozpościera się widok na Wisłę - est skrytka „Wawel” (http://www.gcmalo polska.pl). Wały wiślane to miejsce szczególne ze względu na koncentrację na nim aż 210 tradycyjnych skrzynek. Seria ta ciągnie się po obu stronach rzeki od samego Wawelu aż po położony ponad $20 \mathrm{~km}$ dalej most w Łaczanach. Typowe proste skrzynki mieszaja się z przemyślnym maskowaniem i stanowią prawdziwy raj dla keszerów. Kesze upamiętniające historyczne wydarzenia - w tym przypadku tragiczne czasy II wojny światowej - założone zostały nieopodal dawnej siedziby gestapo przy ulicy Pomorskiej 2 oraz na terenach kamieniołomów, w bezpośrednim sąsiedztwie obozu koncentracyjnego Płaszów. W obu przypadkach skrytki zachwycają nieprzeciętnym maskowaniem, nie ingerują $\mathrm{w}$ oryginalne otoczenie oraz stanowią prawdziwy wzór dla każdego keszera. Kraków ma za sobą wiele stuleci pełnych niezwykłych wydarzeń, a tutejsi keszerzy robią wszystko, by pokazać najciekawsze $\mathrm{z}$ nich (http://www.gcmalopol ska.pl).

Inny ciekawy projekt - tym razem o tematyce przyrodniczej - zrealizowano w otoczeniu Wrocławia. „Ptaki Polski" to niedługa ścieżka przyrodnicza opublikowana w 2016 r., mająca na celu zachęcenie do odwiedzenia wodonośnych terenów okolic Wrocławia. Obszar ten jest szczególnie ceniony przyrodniczo, ponieważ stanowi ekologiczny korytarz doliny Odry i miejsce lęgowe wielu gatunków ptaków, które są bohaterami tego projektu (https:/ / opencaching.pl/power trail.php?ptAction=showSerie\&ptrail=519).

\section{TRASY TERENOWE NA OBSZARACH WIEJSKICH}

Lokalne organizacje, powoływane zwykle na terenach niewielkich miast i wsi, skupiają najczęściej najbardziej aktywnych ich mieszkańców. Struktury, takie jak LGD-y, LOT-y, wykazują duże zaangażowanie w rozwój usług turystycznych, kultywowanie tradycji i propagowanie zdrowego trybu życia. Geocaching, dający możliwość połączenia tych wszystkich przymiotów, stał się doskonałym narzędziem promującym ciekawe pod względem turystycznym miejsca na obszarach wiejskich.

Geocaching w Nowym Tomyślu (Wielkopolska) polega na odnajdywaniu pojemników, w których schowane są naklejki. Umieszczone na nich zdjęcia nawiązują do ciekawych obiektów turystycznych i historycznych znajdujących się na terenie gminy, a zebranie wszystkich naklejek upoważnia do odebrania w Gminnym Ośrodku Informacji specjalnego certyfikatu 
oraz gadżetu - niespodzianki (http:/ / opencaching.pl/ powerTrail.php?ptAction=showSerie\&ptrail=141).

Pomysłodawcą tego projektu jest mieszkaniec Nowego Tomyśla - Bartosz Rajewski, który w 2013 r. zgłosił się z nim do Wydziału Rozwoju i Promocji Urzędu Miasta (http:/ / nowytomysl.pl). Dzięki nawiązanej współpracy powstały dwie ścieżki geocachingowe: "Skarby wiklinowego grodu - geocaching po Nowym Tomyślu” i "Miejsca zwykłe i niezwykłe - geocaching po gminie Nowy Tomyśl" (http:/ / nowy tomysl.nowinylokalne.pl).

Czynny udział w promocji zarówno nowotomyskiej gminy, jak i założeń geocachingu, bierze Muzeum Wikliniarstwa i Chmielarstwa, stanowiące także jeden z etapów keszowych poszukiwań. W ramach projektu "Skarby wiklinowego grodu - geocaching po Nowym Tomyślu" poszczególne skrytki można odnaleźć w pobliżu wpisanego do Księgi Rekordów Guinnessa kosza giganta, przy wiklinowej muszli koncertowej i na wiklinowym deptaku (http://www.geopyra.pl/ 2015/04/geocaching...).

Podróż po gminie Nowy Tomyśl turysta może odbyć także dzięki wspominanemu projektowi „Miejsca zwykłe i niezwykłe - geocaching po gminie Nowy Tomyśl". Podczas poszukiwań keszy natrafi on zarówno na obiekty kultu religijnego (kościoły w Wytomyślu, Bukowcu i Sątopach), jak i na zabytkowe budowle mieszkalne, takie jak: dworek w Starym Tomyślu i chata olęderska w Grubsku oraz niegdyś użytkowane wiatraki w Paproci i Borui Kościelnej (http:/ / www.pnt.info.pl).

Lokalna Organizacja Turystyczna (LOT) „Serce Kaszub" wyznaczyła na terenie powiatu kościerskiego siedem rowerowych tras wycieczkowych, wokół których powstało 40 skrzynek geocachingowych. Wszystkie zostały zarejestrowane $\mathrm{w}$ serwisie www.open cachingi.pl i uwzględniają niezbędne dane do ich odnalezienia (współrzędne geograficzne, atrybuty skrzynki, opis atrakcji i zdjęcia) (http://lot-serce kaszub.pl).

Najdłuższa trasa, o długości $41 \mathrm{~km}$, o nazwie "Między Wierzycą a Wietcisą" wiedzie od Będomina, drogami gruntowymi oraz leśnymi duktami, przez malownicze tereny na południu Kaszub. W drodze uczestnik gry mija m.in. XVII-wieczny kościół barokowy (Grabowo Kościerskie), historyczny dworek - miejsce urodzenia Józefa Wybickiego, a obecnie Muzeum Hymnu Narodowego oraz karczmę z XIX w. w Lubieszynie (http:/ / lot-sercekaszub.pl/portfolios/trasarowerowa-miedzy-wierzyca-a-wietcisa).

Najkrótsza, 25-kilometrowa trasa „W kościerskich lasach" pozwalająca poznać okolice Kościerzyny, biegnie wśród niekończących się lasów i malowniczych krajobrazowo wsi. W miejscowości Łubiana warto zatrzymać się przy sklepie z ceramiką produkowaną przez Zakłady Porcelany Stołowej, a we wsi Owśnice obejrzeć Diabelski Kamień (http:/ / lot sercekaszub.pl/ portfolios/trasa-rowerowa-w-koscierskich-lasach).

Wszystkie trasy prowadzą przez charakterystyczne tereny Kaszub, dając możliwość zapoznania się z walorami przyrodniczymi i kulturowymi regionu.

\section{GEOCACHING NA OBSZARACH CHRONIONYCH}

Ze względu na wzrost zainteresowania turystyką ekologiczną ściśle związaną z przyrodą, wielu uczestników geocachingu rozmieszczając swoje skrytki zakłada je w interesujących pod względem przyrodniczym lub krajobrazowym miejscach. W związku z tym zarówno na świecie, jak i w Polsce, nowe kesze zakładane są m.in. w parkach narodowych i na innych cennych przyrodniczo terenach. Skrytki te muszą spełniać jednak liczne kryteria zgodne $\mathrm{z}$ regulaminem (www.geocaching.com) oraz zasadami funkcjonowania poszczególnych obszarów chronionych.

Stowarzyszenie Geocaching Polska, dla którego zgodnie ze statutem ważna jest dbałość o środowisko naturalne, współpracuje $\mathrm{z}$ administracjami parków narodowych i Lasami Państwowymi w zakresie poszanowania i ochrony środowiska poprzez promowanie nowoczesnego charakteru edukacji proekologicznej. Na stronie internetowej serwisu geocaching można znaleźć dokładne informacje o zasadach rozmieszczania keszy w trzech parkach narodowych. W Kampinoskim PN i Wigierskim PN prawnie unormowano sposób i miejsca zakładania skrytek, a w Ojcowskim PN ustanowiono całkowity zakaz ukrywania „skarbów" (http://geocaching-z pomyslem.blogspot. com...). W przypadku pozostałych terenów przyrodniczo cennych zalecaną praktyką jest uzgodnienie umieszczenia skrzynek $\mathrm{z}$ gospodarzami terenu (np. nadleśnictwa, zarządy parków). Precyzując sposób instalowania skrzynek w Kampinoskim PN należy wspomnieć, że niedopuszczalne jest uszkadzanie drzew i innych elementów przyrody oraz zakopywanie keszy. Można natomiast przymocować skrytki za pomocą magnesu do tablic informacyjnych. W Wigierskim PN wymagania są podobne. Każdy, kto chce założyć kesz na jego terenie, musi osobiście złożyć wniosek w Dyrekcji i przedstawić pojemnik, sposób maskowania oraz wskazać na mapie miejsce ukrycia. Umieszczenie skrytki odbywa się pod kontrolą wskazanego leśnika na terenie wcześniej uzgodnionym.

Wigierski PN jest pierwszym parkiem narodowym w Polsce $\mathrm{i}$ jednym $\mathrm{z}$ pierwszych $\mathrm{w}$ Europie, który ma na swoim obszarze oficjalny szlak geocachingowy (inaczej geościeżkę). Składa się on z blisko 40 skrytek, tzw. geocache, ukrytych wokół jeziora 
Wigry, oraz wirtualnych keszy geologicznych, tzw. earthcache, które zakładane są w miejscach szczególnie ciekawych pod względem geologicznym. Każda skrzynka posiada swój profil na stronie geocaching. com, gdzie podane są współrzędne, opis danego miejsca i ukrycia oraz zasady przebywania w Wigierskim PN. Wszystkie te informacje podane są $\mathrm{w}$ językach polskim, angielskim oraz niemieckim, co zachęca do poszukiwań osoby z całego świata (PAJER-GIEŁAŻYS 2014). Nowoczesny model rozwoju turystyki w parku narodowym opracowano także w Biebrzańskim PN (RĄKOWSKI 1993). Główny nacisk położono w nim na dopuszczenie na obszarze chronionym tylko takich form ruchu turystycznego, które nie zagrażałyby najcenniejszym zasobom przyrodniczym.

Jedną z najciekawszych według autorki inicjatyw łączaccych podniesienie wiedzy na temat fauny i flory, promocji walorów przyrodniczych oraz wykorzystania nowoczesnych technologii (GPS) przy aktywnym spędzaniu czasu jest geocachingowe zadanie pod nazwą „Rowerowi poszukiwacze skarbów”, służące edukacji przyrodniczej na terenach objętych ochroną przyrody $\mathrm{w}$ powiecie wołomińskim (http://powiat wolominski.pl). W pobliżu wybranych cennych przyrodniczo miejsc władze powiatowe założyły 15 skrzynek geocachingowych, które oceniane są przez uczestników gry jako znakomite (https://opencaching. $\mathrm{pl} /$ viewcache.php?cacheid=44098). Rozmieszczone w trzech lokalizacjach: Białe Błota, Dolina Liwca i Ostoja Nadbużańska, zachęcają do odwiedzenia i służą podniesieniu wiedzy ekologicznej. Na tablicach edukacyjnych rozstawionych wzdłuż każdej z tras umieszczono dodatkowo informacje o obiektach prawnie chronionych położonych w najbliższej okolicy. W pobliżu miejsc ukrycia skarbów urzędnicy starostwa zadbali o środki transportu keszerów, ustawiając stojaki rowerowe i wyznaczając dogodne parkingi dla samochodów.

\section{POWIAT POZNAŃSKI PREDESTYNOWANYM DO ROZWOJU GEOCACHINGU}

Region powiatu poznańskiego nie jest ważnym obszarem wypoczynkowym w skali krajowej, ale służy turystyce świątecznej lub wypoczynkowi urlopowemu własnych mieszkańców (MATUSZEWSKA 2008). Wielkopolski Park Narodowy, parki krajobrazowe, rezerwaty, lasy i parki determinują znaczącą rolę przyrody w tej części województwa wielkopolskiego, stanowią naturalny skarb i są wymarzonym miejscem do celów rekreacyjnych. Liczne zabytki, a wśród nich zespoły parkowo-pałacowe, dworskie, zamkowe i wiejskie dowodzą bogatej historii tej ziemi, decydują o wy- sokiej pozycji pośród obiektów krajoznawczych i są dumą podpoznańskich gmin (Łęcki, red. 2015).

Poza formalnymi społecznościami (koncentrującymi się wokół takich struktur, jak: Geocaching Polska czy PTTK) miłośnicy omawianej gry terenowej działają na obszarze powiatu poznańskiego indywidualnie lub tworzą grupy razem keszujące i posiadające wspólne konto na portalach geocaching lub opencaching.

Wśród najciekawszych utworzonych geościeżek na szczególną uwagę zasługują:

- „Pierścień Rowerowy Dookoła Poznania”,

- "Pałace i dwory Wielkopolski”,

- „Wartą do Poznania”,

- "Puszcza Zielonka - Śladami Wiary”,

- „Swarzędzkie Keszowanie”.

Zarządzany przez Urząd Marszałkowski Województwa Wielkopolskiego „Pierścień Dookoła Poznania" to najbardziej popularny wśród poznańskich cyklistów szlak rowerowy. Ze względu na swoją strukturę - nie ma początku ani końca, jest bowiem pętlą - można do niego dotrzeć z Poznania jednym z siedmiu szlaków łącznikowych, biegnących z każdej strony miasta (http://www.gpswielkopolska.pl). Łączna długość pierścienia wynosi $173 \mathrm{~km}$, a szlaków dojazdowych - 123,2 km. Dzięki łącznikom można zaplanować niepowtarzalne, niezbyt długie wycieczki, podczas których warto zwiedzić okoliczne zabytki i zachwycić się pięknem przyrody (http://trail.pl) Przemieszczając się niezwykle ciekawą trasą turysta w mniejszych miejscowościach zobaczy m.in. zabytki architektury (Rogalin, Bnin, Wronczyn), obiekty sakralne - kościoły o późnoromańskim charakterze (Tulce, Dąbrówka Kościelna, Skórzewo), ciekawostki przyrodnicze i krajobrazowe (np. źródełko Żarnowiec ze strumieniem o górskim charakterze, "Zielonkę" - placówkę badawczą Uniwersytetu Przyrodniczego z ciekawym arboretum, rezerwat "Meteoryt Morasko") (http:/ / regionwielkopolska.pl).

Od kiedy 23.05.2015 r. odbył się w Poznaniu event zorganizowany przez keszera "PiotrMicha1", przy współudziale innych zapalonych poszukiwaczy, „Pierścień Rowerowy Dookoła Poznania” stał się także projektem keszingowym. Trasa została podzielona na 22 odcinki po 10-12 km nadzorowane przez geoprylandczyków z Wielkopolski i obsadzona skrzynkami co około $500 \mathrm{~m}$. Przedsięwzięcie, które ze wzglę$\mathrm{du}$ na rozmach jest ciągle $\mathrm{w}$ fazie rozwoju, planowane jest na około 440 keszy z finałową skrzynią w okolicach Puszczy Zielonki (http://www.geopyra.pl/ 2015/05/pierscien.html).

„Pałace i Dwory Wielkopolski” to kolejna fascynująca geościeżka tworzona wspólnie przez pasjonatów historii. Na 30.03.2017 r. na trasie istnieje 91 skrzynek umieszczonych w pobliżu zabytkowych obiektów na obszarze niemal wszystkich gmin powiatu poznań- 
skiego. W bliskiej odległości od Poznania w Zakrzewie, położonym w gminie Dopiewo, założono niezwykłą geościeżkę zatytułowaną „Mogiły Zakrzewskie". Kesze pod szczególnymi nazwami: Pomnik Studentów, Miejsce Zapomniane, Mogiła Duchownych i Kwatera Siedmiu Grobów, upamiętniają historię okresu wojennego i masowe egzekucje polskich obywateli na tym terenie (http://opencaching.pl/ viewcache.php?cacheid=46404).

Przyrodnicze walory powiatu poznańskiego przybliżają szczególnie dwa bardzo interesujące szlaki. Pierwszy z nich - „Wartą do Poznania" - to seria skrzynek ukrytych wzdłuż Warty na obszarze Poznańskiego Przełomu Warty. Trasa zaczyna się w okolicach Rogalinka i brzegiem rzeki wiedzie do Głuszyny Leśnej, Kubalina, Rogalina Podlesia i Daszewic. Trasa geościeżki przecina się ze szlakami rowerowymi Łabędzim i Rogalińskim, a kończy w parku krajobrazowym w okolicach Czmońca, zahaczając po drodze o Bobrowy Szlak - ciekawą ścieżkę przyrodniczo-dydaktyczną (http:/ / opencaching.pl/powerTrail.php?pt Action $=$ showSerie\&ptrail=229).

Drugi projekt - „Puszcza Zielonka” - prezentuje toponimy - lokalne nazwy terenowe miejsc będaccych świadectwem zmian zachodzących na terenie lasu przez lata. Tworzone przez ludność miejscową, leśników, myśliwych i turystów nazwy wiosek i wsi, stały się doskonałym pomysłem na założenie geościeżki. Kesze ukryte na terenie gmin Kiszkowo, Czerwonak, Murowana Goślina, Pobiedziska i Skoki intrygują urozmaiconą rzeźbą terenu i zachowanym naturalnym kompleksem leśnym.

Puszcza Zielonka to także „bohaterka” geościeżki „Śladami Wiary po Puszczy Zielonka” - keszerskiego projektu przedstawiającego cmentarze ewangelickie, na których grzebano głównie Niemców przed II wojną światową. Dzięki temu innowacyjnemu projektowi podjęto próbę ratowania podupadłych i zapomnianych nekropolii, które oprócz miejsc pamięci, są także skarbnicą starych gatunków roślin. W większości są to ozdobne 100-letnie żywotniki, daglezje, choiny kanadyjskie, a wśród rodzimych gatunków dominują dęby, lipy, jawory i kaliny (GIŻYCKA, SOBALAK 2013). Kwitnące wiosną śnieżyce i śnieguliczki, zachęcają do podejmowania skrzynek na tych terenach.

"Swarzędzkie keszowanie" jako projekt złożony z dziesięciu małych mikroskrzynek, eksponuje najciekawsze pod względem przyrodniczym i krajoznawczym oraz historycznym miejsca na terenie Swarzędza. Kesze umieszczono m.in. na Plantach - placu Niezłomnych, obok Pawilonu Meblowego Stolarzy Swarzędzkich oraz przy dworcu kolejowym, którego główny budynek wybudowany został w 1887 r. (https:/ / opencaching.pl/viewcache.php?wp=OP431B).

Szczególną ciekawostką łączącą Swarzędz z wcześniej omawianą Puszczą Zielonką jest opracowanie i za- instalowanie przez nauczycieli matematyki i grupe uczniów z I LO na terenie Puszczy około 30 skrzynek typu quiz, do których dotarcie możliwe jest po wykonaniu pomiarów, obliczeń, rozwiązaniu zadań, rebusu lub łamigłówki. Celem twórców tej edukacyjnej zabawy było połączenie zajęć na atrakcyjnych terenach powiatu poznańskiego $\mathrm{z}$ popularyzacją matematyki jako jednej z najtrudniejszych nauk. Warto dodać, że projekt „Daj się uwieść matematyce, czyli ekos-math-geocaching" otrzymał dofinansowanie Fundacji mBanku w III edycji Programu mPotęga skierowanego do szkół podstawowych, gimnazjalnych i ponadgimnazjalnych, organizacji pozarzadowych i grup nieformalnych z całej Polski (http:/ / swarzedz.pl).

Wiele z działań geocachingowych na terenie powiatu poznańskiego inicjowanych jest przez funkcjonującą na obszarze Wielkopolski GEOpyrę. Należy ona do najliczniejszych stowarzyszeń geocachingowych w Polsce (492 aktywnie działające osoby - 18.07. 2017 r., https://www.facebook.com/groups/8420198 99257553). Jej członkowie przedstawiają siebie jako „współczesną grupę poszukiwaczy skarbów z Poznania i jego okolic, którzy aktywnie spędzając czas szukają zawsze, wszędzie i z uśmiechem na ustach robią wpisy w kolejnych odnalezionych keszach" (http:/ / www.geopyra.pl/p/o-nas.html).

Początkowo geocaching w Wielkopolsce znacznie odstawał statystycznie od innych regionów w kraju pod względem liczby rozmieszczonych skrzynek. Dopiero od 6.09.2014 r., kiedy zafascynowany grą pasjonat - Jakub Chęciński (Udash69) - spotkał się z grupą kilkunastu osób na wspólnej wyprawie rowerowej, której efektem było m.in. stworzenie szlaku „Keszostrada", datuje się rozwój geocachingu w Wielkopolsce. Już w październiku 2014 r. Udash69 wraz ze współpomysłodawcą Wantskym (Posnanian Reveiewer) założyli grupę na Facebooku oraz blog www. geopyra.pl. Nazwa społeczności nie była przypadkowa. GEOpyra to połączenie pierwszego członu Geocachingu oraz pochodzącej z gwary poznańskiej „pyry" (ziemniaka), która jednoznacznie klasyfikuje grupę w określonym regionie Polski (http:/ / geocache.pl).

W pierwszym okresie działalności zwolennicy zabawy zainstalowali ponad 1000 wielkopolskich skrytek, zaprojektowali własne pieczątki i tysiące logbooków (papierowy dzienniczek wpisów schowanych w keszu) z nickiem i logiem GEOpyry. Grupa podjęła także współpracę z hostelem PocoLoco, oferującym dla przyjezdnych keszerów zniżki ( $10 \%$ na hasło GEO pyra) na nocleg w Poznaniu, oraz aktywnie prowadzi bloga, na którym relacjonuje spotkania, wyjazdy, eventy i projekty. Kilka lat aktywności GEOpyry pozwoliło zaistnieć jej zarówno w samym Poznaniu, jak i na obszarze Wielkopolski.

Skupiając się na grodzie Przemysła, czyli Poznaniu, szczególnym uznaniem geopyrlandczyków cieszą 
się skrytki umiejscowione nieopodal pomnika Enigmy, Hotelu Naramowice, lasu wokół Moraska, osiedla Strzeszyn Grecki i Zagrody Bamberskiej przy ulicy Kościelnej. Każda z tych skrzynek, ukryta w szczególnie interesujący sposób i w niekonwencjonalnym otoczeniu, pozwala znalazcy poznać fragment historii miejsca i przeżyć ciekawą przygodę (http:/ / geocache. pl).

Stowarzyszenie GEOpyra prowadzi także szereg działań proekologicznych, np. CITO (Cache In Trash Out), organizowany od 2002 r., ściśle związany z geocachingiem: w trakcie poszukiwań skrytek uczestnicy gry zbierają śmieci leżące po drodze i przeznaczają je do właściwej utylizacji. Wydarzenia CITO są akcjami oczyszczania środowiska, w które zaangażowana jest szersza światowa społeczność (https://www.geoca ching.com/cito).

Pierwszy wielkopolski weekend CITO odbył się 25.04.2015 r., a jego ideą była troska o stan okolicznych lasów. Użytkownicy serwisu geocaching i opencaching wystąpili do Nadleśnictwa Łopuchówko z propozycją posprzątania dowolnego terenu leśnego. Keszerzy "otrzymali" pas lasu sąsiadujący z drogą biegnącą od Radojewa (stanowiącego część miejskiego osiedla Morasko-Radojewo) do Biedruska, na którym zebrano około 4000 litrów śmieci. Nagrodą za ciężką pracę była możliwość uczestniczenia w lekcji przyrody - poszukiwacze keszy (a właściwie, tym razem, śmieci) zostali oprowadzeni po ekspozycji i salach szkoleniowych w Ośrodku Edukacji Leśnej Łysy Młyn (http:/ / www.geopyra.pl/2015/04/1-cito...). Ostatnie wydarzenia związane $\mathrm{z}$ wycinaniem drzew szczególnie wzmogły ekologiczną aktywność GEOpyry. W pierwszym dniu kwietnia 2017 r., korzystając z gościnności Nadleśnictwa Taczanów, członkowie keszerskiej społeczności zorganizowali akcję sadzenia nowych drzewek i odnowienia kawałka lasu (https:// www.geocaching.com/geocache/GC71R0D_sadzimylas).

Czas pomiędzy 22 a 30 kwietnia to jeden z dwóch (kolejny we wrześniu) zaplanowanych w 2017 r. tygodni Cache In Trash Out ${ }^{\circledR}$. W tym właśnie czasie geokeszerzy na całym świecie założyli gumowe rękawiczki, wzięli worki na śmieci i ruszyli na wielkie sprzątanie. W ramach eventu CITO w powiecie poznańskim odbyło się $\mathrm{w}$ tym czasie sprzątanie okolic Jeziora Swarzędzkiego i Lasku Winiarskiego (http:/ / www.geopyra.pl/p/spotkania.html).

Podsumowując działalność wielkopolskich keszerów warto wspomnieć o organizowanych przez nich spotkaniach, które służą promocji geocachingu w regionie. 10 czerwca odbył się XIV World-Wide Flash Mob (WWFM), czyli międzynarodowy projekt, podczas którego pasjonaci zabawy spotykają się na całym świecie o tej samej porze, aby zrobić wspólne zdjęcie. Zabawny i przyjazny sposób szerzenia idei geo- cachingu odbył się w tym roku w 80 krajach, a motywem przewodnim były balony i biały ubiór uczestników (http:/ / www.gcwwfm.com/about-us).

Kolejne dwie imprezy organizowane były w pierwszych dniach wakacji (23 i 24.06.), czyli Poznański Nocny Event Rowerowy i event „Holiday 2017” zachęcały do spotkań w gronie keszerskiej społeczności, rozmów na typowe dla nich tematy; wymiany fantów i aktywnego spędzenia czasu.

Percepcja geocachingu przez mieszkańców powiatu poznańskiego to temat ankiety zredagowanej przez autorkę niniejszego artykułu i przeprowadzonej w formie papierowej oraz udostępnionej za pośrednictwem Internetu w mediach społecznościowych - Facebook, na fanpage'ach gmin omawianego powiatu oraz stron www lokalnych atrakcji (m.in. wieża widokowa w Osowej Górze i Mosińskiej Kolei Drezynowej) w ramach pracy magisterskiej przygotowanej na Uniwersytecie Przyrodniczym w Poznaniu. Badanie przeprowadzono na grupie 376 respondentów, z których 21 nie poradziło sobie $\mathrm{z}$ zadanymi pytaniami lub nie zrozumiało ich treści (są to ankiety nieważne). Anonimowa ankieta zawierała 11 pytań, które mają wykazać zarówno znajomość zjawiska geocachingu, przybliżyć autorce zainteresowania turystyczne respondentów, jak i ocenić ich dostęp do technologii informatycznych. Zawarte w części metryczkowej pytania o płeć, wiek, wykształcenie i miejsce zamieszkania pozwoliły uzyskać przekrój demograficzno-społeczny badanej populacji. W badaniu wzięło udział więcej kobiet niż mężczyzn i stanowiły one aż $61 \%$ ogółu badanych (SKÓRA 2017).

Mieszkańcy powiatu poznańskiego, uczestniczący w badaniach przeprowadzonych przez autorkę, wyraźnie zadeklarowali zainteresowanie tematyką geocachingu. Należy podkreślić, iż $82 \%$ badanych stanowiły osoby z przedziału wiekowego od 19 do 50 roku życia mając wykształcenie wyższe i średnie. Aż 52\% badanych (spośród 355 osób) nie znało wcześniej określenia "geocaching". Jednakże mimo to, po wyjaśnieniu, aż $82 \%$ z nich wyraziło chęć udziału w takiej grze. Co ciekawe, respondenci, którzy znali istotę geocachingu, najczęściej czerpali wiedzę o nim od znajomych oraz z Internetu. Aż $49 \%$ badanych mieszkańców powiatu zadeklarowało, że zwiedza analizowany obszar kilka razy w ciągu roku, ale jedynie 3\% z nich czyni to za sprawą sygnału GPS (zdecydowana większość respondentów odwiedza teren $z$ pomocą własnego przewodnika - książkowego lub internetowego). Podkreślić trzeba, że $98 \%$ ankietowanych posiada stały dostęp do Internetu, a aż 58\% ogółu surfuje w wirtualnej przestrzeni za pomocą telefonu komórkowego i tableta. Powyższe wyniki dobrze prognozują w kontekście rozwoju zainteresowania geocachingiem w powiecie poznańskim. 


\section{PODSUMOWANIE}

Zmieniajace się potrzeby turystyczne i metody ich zaspokajania przez współczesne pokolenia skłaniają do poszukiwania nowych sposobów prezentacji i interpretacji walorów. Niewątpliwie sposobem zyskującym coraz więcej zwolenników jest geocaching. Bogactwo walorów (przyrodniczych i kulturowych) powiatu poznańskiego, prężnie działające społeczności indywidulanych keszerów i koordynacja wielu działań przez organizację o silnych korzeniach regionalnych (GEOpyra), w połączeniu z pozytywnym nastawieniem mieszkańców, stwarzają dogodne warunki do rozwijania i propagowania tej formy gry terenowej. W świetle dotychczas realizowanych projektów geocachingowych należy sądzić, że może mieć ona coraz większe znaczenie w budowaniu współczesnego wizerunku krajoznawstwa.

\section{PRZYPIS}

${ }^{1}$ Artykuł powstał na podstawie pracy magisterskiej autorki zatytułowanej Geocaching w powiecie poznańskim jako innowacyjna forma odkrywania dziedzictwa przyrodniczego $i$ kulturowego w Uniwersytecie Przyrodniczym w Poznaniu (promotor: dr inż. Sylwia Graja-Zwolińska).

\section{BIBLIOGRAFIA}

DobeK M., KozIEŁ M., 2015, Geocaching w Roztoczańskim Parku Narodowym, „Annales Universitatis Mariae Curie-Skłodowska. Sectio B, Geographia, Geologia, Mineralogia et Petrographia", 70, 2, s. 191-207.

GiŻYCKA M., SOBALAK T.M., 2013, Śladami wiary po Puszczy Zielonka. Przewodnik, Związek Międzygminny Puszcza Zielonka, Murowana Goślina.

ŁĘCKI W. (red.), 2015, Leksykon krajoznawczo-turystyczny powiatu poznańskiego, Powiat Poznański, Poznań

MATHERSON L., WRIGHT V.H., INMAN C.T., WILSON E.K., 2008, Get up, get out with geocaching: Engaging technology for the social studies classroom, "Social Studies Research \& Practice", 3, 3, s. 80-85.

MATUSZEWSKA D., 2008, Stan i struktura przestrzenna bazy noclegowej powiatu poznańskiego, [w:] T. Kaczmarek, A. Mizgajski (red.), Powiat poznański. Jakość przestrzeni $i$ jakości życia, Bogucki Wyd. Naukowe, Poznań, s. 221-238.

PAJER-GIE€AŻYS P., 2014, „Wigry”, Geocaching w Wigierskim Parku Narodowym, „Wigierski Park Narodowy", 1.

RĄKOWSKI G., 1993, Koncepcja rozwoju turystyki na terenie Biebrzańskiego Parku Narodowego i jego otuliny, „Problemy Turystyki", 4 .

SHERMAN E., 2004, Geocaching: hike and seek with your GPS, Apress, Berkeley CA.

SKÓRA J.M., 2017, Geocaching w powiecie poznańskim jako innowacyjna forma odkrywania dziedzictwa przyrodniczego $i$ kulturowego, praca magisterska, Uniwersytet Przyrodniczy w Poznaniu.
SMOLEŃSKA O., 2009, Najnowsze trendy w turystyce eventowej. Gry fabularne i wydarzenia zwiqzane z fantastykq i technologia XXI wieku, „Turystyka Kulturowa”, 8, s. 31-38.

Statut Polskiego Towarzystwa Turystyczno-Krajoznawczego; tekst jednolity, uwzględniający zmiany uchwalone 14.04 . 2012 r. przez Nadzwyczajny Zjazd Polskiego Towarzystwa Turystyczno-Krajoznawczego.

Uchwała z 25 lutego 2012 r. nr 311/XVII/2012 Zarządu Głównego PTTK odznaki PTTK Geocaching Polska.

Wielki stownik angielsko-polski, polsko-angielski PWN-Oxford, 2012, Wyd. Naukowe PWN, Oxford University Press.

http://geocache.pl/uncategorized/2015/geocaching-w-wielko polsce-geopyra/; 3.04.2017.

http:/ /geocaching-z-pomyslem.blogspot.com/2016/04/tere ny-chronione.html; 18.07.2017.

http://ibedeker.pl/wydarzenie/zwiedzanie-przez-szukanieczyli-geocaching-w-gdansku/; 13.03.2017.

http:/ / lot-sercekaszub.pl/portfolios/geocaching-w-sercuka szub-2/; 14.03.2017.

http:/ / lot-sercekaszub.pl/portfolios/trasa-rowerowa-miedzywierzyca-a-wietcisa/; 14.03.2017.

http:/ / lot-sercekaszub.pl/portfolios/trasa-rowerowa-w-kos cierskich-lasach/; 14.03.2017.

http:/ / nowytomysl.nowinylokalne.pl/geocaching-nowym-to myslu/; 14.03.2017.

http://nowytomysl.pl/wiadomosci/wydarzenia/geocachingpo-nowym tomyslu; 14.03.2017.

http:/ / opencaching.pl/powerTrail.php?ptAction=showSerie\& ptrail=141; 14.03.2017.

http:/ / opencaching.pl/powerTrail.php?ptAction=showSerie\& ptrail=229; 3.04.2017.

http:/ /opencaching.pl/viewcache.php?cacheid=46404; 3.04.2017

http:/ / powiatwolominski.pl/index.php?cmd=aktualnosci\&op $\mathrm{t}=$ pokaz\&id=1805; 27.04.2017.

http://regionwielkopolska.pl/turystyka/szlakiturystyczne/s zlakiturystyczne/szlaki.owerowe/szlaki-w-okolicach-poz nania-971.html; 3.04.2017.

http:/ / swarzedz.pl/index.php?id $=49 \&$ no cache $=1 \&$ tx ttnews $\% 5 \mathrm{Btt} \_$news $\% 5 \mathrm{D}=124 \& \mathrm{tx} \_t \mathrm{tws} \% 5 \mathrm{BbackPid} \% 5 \mathrm{D}=10 \& \mathrm{c}$ Hash=063d4ad5449e287bbfa212810d402d4b; 3.04.2017.

http:/ / trail.pl/szlaki/ pierscien-rowerowy-dookola-poznania1256; 3.04.2017.

http://www.gcmalopolska.pl/pl/geocaching-malopolska/11atrakcje/64-najlepsze-skrytki-tradycyjne-w-krakowie; 14.03.2017.

http://www.gcwwfm.com/about-us; 31.05.2017.

http://www.gdansk.pl/wydarzenia/Miejska-gra-geocachin gowa-Szukajcie-azwiedzicie,w,19310; 13.03.2017.

http:/ / www.geopyra.pl/2015/04/1-cito-geopyry-ysy-myn2015-relacja.html; 3.04.2017.

http://www.geopyra.pl/2015/04/geocaching-z-albumemgeopyra-w-nowym.html; 14.03.2017.

http:/ / www.geopyra.pl/2015/05/pierscien.html; 3.04.2017.

http://www.geopyra.pl/p/o-nas.html; 3.04.2017.

http://www.geopyra.pl/p/spotkania.html; 3.04.2017.

http:// www.gpswielkopolska.pl/na-rower/33-pierscien-rowe rowy-dookola-poznania; 3.04.2017.

http://www.pnt.info.pl/news.php?readmore $=2341 ; 14.03 .17$. http://www.pttk.pl/ks3/dok/k17_u311_z01_20120225.pdf; 22.02.2017.

https://opencaching.pl/powerTrail.php?ptAction=showSerie \&ptrail=519; 26.04.2017.

https:/ / opencaching.pl/viewcache.php?cacheid=44098; 9.10 2017. 
https://opencaching.pl/viewcache.php?wp=OP431B; 9.10.2017. https://www.facebook.com/groups/842019899257553/.

https://www.geocaching.com/blog/2017/04/3-million-geocaches-the-infographic/.

https://www.geocaching.com/cito/; 3.04.2017.

https://www.geocaching.com/geocache/GC71R0D_sadzimylas; 3.04.2017. https:/ / www.geocaching.org.pl/stowarzyszenie/kim-jestes $\mathrm{my} / ;$ 10.03.2017.

https://www.geocaching.org.pl/stowarzyszenie/statut/; 10.03.2017. 
